Article

\title{
Soldering Characteristics and Mechanical Properties of Sn-1.0Ag-0.5Cu Solder with Minor Aluminum Addition
}

\author{
Yee Mei Leong and A.S.M.A. Haseeb * \\ Centre for Advanced Materials, Department of Mechanical Engineering, Faculty of Engineering, \\ University of Malaya, Kuala Lumpur 50603, Malaysia; leongyeemei@siswa.um.edu.my \\ * Correspondence: haseeb@um.edu.my; Tel.: +60-3-79674492
}

Academic Editor: Geminiano Mancusi

Received: 26 May 2016; Accepted: 16 June 2016; Published: 28 June 2016

\begin{abstract}
Driven by the trends towards miniaturization in lead free electronic products, researchers are putting immense efforts to improve the properties and reliabilities of Sn based solders. Recently, much interest has been shown on low silver $(\mathrm{Ag})$ content solder SAC105 $(\mathrm{Sn}-1.0 \mathrm{Ag}-0.5 \mathrm{Cu})$ because of economic reasons and improvement of impact resistance as compared to SAC305 (Sn-3.0Ag-0.5Cu. The present work investigates the effect of minor aluminum (Al) addition (0.1-0.5 wt. \%) to SAC105 on the interfacial structure between solder and copper substrate during reflow. The addition of minor $\mathrm{Al}$ promoted formation of small, equiaxed $\mathrm{Cu}-\mathrm{Al}$ particle, which are identified as $\mathrm{Cu}_{3} \mathrm{Al}_{2}$. $\mathrm{Cu}_{3} \mathrm{Al}_{2}$ resided at the near surface/edges of the solder and exhibited higher hardness and modulus. Results show that the minor addition of $\mathrm{Al}$ does not alter the morphology of the interfacial intermetallic compounds, but they substantially suppress the growth of the interfacial $\mathrm{Cu}_{6} \mathrm{Sn}_{5}$ intermetallic compound (IMC) after reflow. During isothermal aging, minor alloying $\mathrm{Al}$ has reduced the thickness of interfacial $\mathrm{Cu}_{6} \mathrm{Sn}_{5} \mathrm{IMC}$ but has no significant effect on the thickness of $\mathrm{Cu}_{3} \mathrm{Sn}$. It is suggested that of atoms of $\mathrm{Al}$ exert their influence by hindering the flow of reacting species at the interface.
\end{abstract}

Keywords: intermetallic; mechanical properties; nanoindentation; interfacial reaction; microstructure; differential scanning calorimetry; scanning electron microscopy; minor $\mathrm{Al}$ addition

\section{Introduction}

Restriction on the use of lead based solder in the electronic industry has led to extensive developments in lead free solders. Driven by the necessity to improve the reliability of lead free electronic products and by the trend towards miniaturization, researchers are putting intense efforts into improving the properties of $\mathrm{Sn}$ based solders. Sn-Ag-Cu (SAC solder) alloys have been a favored replacement for $\mathrm{Sn}-\mathrm{Pb}$ solders. However, the currently used ternary eutectic $\left(\mathrm{T}_{\mathrm{m}}=217^{\circ} \mathrm{C}\right)$ or near eutectic SAC solders have some drawbacks. These SAC solders were reported to have relatively high amount of undercooling $\left(10-30^{\circ} \mathrm{C}\right)$, as $\beta$-Sn requires large undercooling to nucleate and solidify. This large undercooling promotes the formation of large, plate-like $\mathrm{Ag}_{3} \mathrm{Sn}$ structures that have been reported to cause joint embrittlement and reliability problem [1]. Research has been done on solders with lower silver content of, e.g., Sn-1.0Ag-0.5Cu (SAC105), in an attempt to inhibit the formation of $\mathrm{Ag}_{3} \mathrm{Sn}$ and also to reduce the solder cost, as the price of $\mathrm{Ag}$ has increased dramatically in recent years [2-5]. Although it has been reported that SAC105 performs better in drop tests, it has a higher liquidus temperature, which requires a higher reflow profile than the eutectic Sn-3.8Ag-0.7Cu (SAC387) alloy [5]. It also performs poorly in thermal cycling tests [6]. These drawbacks have prompted researchers to modify the solder content by adding small amounts of other alloying elements to further improve its reliability and lower its melting temperature. 
Fourth minor alloying elements (0.05-0.1 wt.\%) that have been added into SAC solder include Ni, $\mathrm{Co}, \mathrm{Fe}, \mathrm{Mn}, \mathrm{Zn}, \mathrm{Ti}, \mathrm{Ce}$, In and Al [7-10]. The effects of the fourth alloying element on the microstructure and mechanical properties have been investigated. Improvements in mechanical properties such as shear strength [10], tensile strength [7], impact resistance [5], and creep resistance [7] have been reported. It has been observed that the addition of fourth alloying elements imparts their influence on the mechanical properties by modifying the microstructure of the solder. It was observed that the fourth alloying element modify the microstructure, by: (i) refining the microstructure of the solder matrix; (ii) suppressing brittle intermetallic compound (IMC) formation; and (iii) changing the morphology of the IMC in solder matrix/interface [11].

The addition of aluminum has attracted much interest in recent years. Research on $\mathrm{Al}$ addition as nanoparticles or minor alloying element has been reported [12-18]. Amagai [12] observed that the addition of $0.05 \% \mathrm{Al}$ nanoparticles did not have any significant effect on the interfacial IMC. As for the addition of aluminum as minor alloying element, a few works on the effect of $\mathrm{Al}$ on the mechanical properties, microstructure and solder/ $\mathrm{Cu}$ substrate interfacial reaction have been reported $[2,9,11,14-18]$. Previous studies have shown that minor addition of $\mathrm{Al}$ gives promising results in suppressing undercooling of $\beta$-Sn and reduced formation of brittle phase $\mathrm{Ag}_{3} \mathrm{Sn}$ in SAC solder matrix [14]. It was found that $\mathrm{Al}$ addition $(0.05 \mathrm{wt} . \%)$ results in excellent shear strength retention after thermal aging at $150{ }^{\circ} \mathrm{C}$ for up to $1000 \mathrm{~h}$. Faizul et al. have investigated the effect of $\mathrm{Al}(0.1-2 \mathrm{wt} . \%)$ on the tensile strength of SAC105 [12,19]. They found that with $0.1 \mathrm{wt} . \% \mathrm{Al}$ addition, $\mathrm{Al}$ reduced the yield strength and ultimate tensile strength (UTS) and promoted ductile fracture. When $\mathrm{Al}$ addition was more than $0.1 \mathrm{wt} . \%$, the yield strength and ultimate tensile strength of the solder increased as a function of $\mathrm{Al}$ content and brittle fracture modes were seen.

A couple of studies dealt with the effects of $\mathrm{Al}$ on the bulk microstructure and interfacial IMC between solder and copper substrate $[15,16,18]$. With the addition of $\mathrm{Al}$ into Sn-Ag (SA) solder, $\mathrm{Al}_{2} \mathrm{Cu}$ IMC and ambiguous Al-Cu IMC were found in the bulk microstructure of SA solder on copper substrate after reflow $[16,18]$. On the other hand, only ambiguous Al-Cu IMC (Anderson et al. reported it as $\left.\delta-\mathrm{Cu}_{33} \mathrm{Al}_{17}\right)$ was found in the bulk microstructure of SAC $[14,19]$. Though the reported effect of $\mathrm{Al}$ on the bulk microstructure seen by other researchers seems consistent, there are contradictory reports on the effects of $\mathrm{Al}$ addition on the interfacial solder/Cu reaction. With addition of $0.5 \mathrm{wt} . \%$ of $\mathrm{Al}$ into SA solder, $\mathrm{Xia}$ et al. observed a spalled layer of $\mathrm{Al}_{2} \mathrm{Cu}$ compound layer near the interface and the suppression of the growth of the $\mathrm{Cu}_{6} \mathrm{Sn}_{5}$ layer. When $\mathrm{Al}$ was added up to $1 \mathrm{wt} . \%$, a layer of $\mathrm{Al}_{2} \mathrm{Cu}$ compound was formed at the solder/Cu interface, which completely replaced $\mathrm{Cu}_{6} \mathrm{Sn}_{5}$ layer [15]. On the other hand, Kotadia et al. reported that spherical Al-Cu IMC spalled away from the solder matrix when $\mathrm{Al}$ was depleted in the solder and there was no suppression of the growth of interfacial $\mathrm{Cu}_{6} \mathrm{Sn}_{5}$ layer when 0.5 to $2.0 \mathrm{wt}$.\% of $\mathrm{Al}$ was added in to SA solder [18]. Li et al. have reported that with the addition of $1 \mathrm{wt} . \% \mathrm{Al}$ into SAC387 solder, layered $\delta-\mathrm{Al}_{2} \mathrm{Cu}_{3}$ formed at the interface after $10 \mathrm{~min}$ reflow and the growth of the $\mathrm{Cu}_{6} \mathrm{Sn}_{5}$ layer was reduced [16]. Dhaffer et al. have investigated the effect of $0.1 . w t . \% \mathrm{Al}$ addition on the interfacial reaction by dipping method, they reported that $0.1 \% \mathrm{Al}$ addition have suppressed the growth of $\mathrm{Cu}_{6} \mathrm{Sn}_{5}$ layer [20]. Until now, no detailed study has been done for the effect of minor $\mathrm{Al}$ addition $(<1 \mathrm{wt} . \%)$ on interfacial reaction of SAC/Cu.

Nanoindentation as a mechanical testing method has attracted a great deal of attraction in many fields of research as it has the ability to measure the properties of sample in extremely small scales such as thin films and coating in nanometer range [21]. This technique is well suited to investigate the mechanical properties of IMCs, which have thicknesses of only several nanometers/micrometers. $\mathrm{Cu}-\mathrm{Al}$ IMC was reported to form in SAC even with addition of as low as $0.05 \mathrm{wt} . \%$ [22]. Besides, it has been reported that $\mathrm{Al}$ is likely to substitute into $\mathrm{Cu}_{6} \mathrm{Sn}_{5}$ as well [14] Previous studies with addition such as $\mathrm{Ni}$, and $\mathrm{Mn}$ have shown that solubility of minor alloying element in $\mathrm{Cu}_{6} \mathrm{Sn}_{5}$ could alter the nanomechanical properties of $\mathrm{Cu}_{6} \mathrm{Sn}_{5}$ [14]. Thus, understanding the mechanical properties of $\mathrm{Cu}-\mathrm{Al}$ IMC and $\mathrm{Cu}_{6} \mathrm{Sn}_{5}$ is essential in the understanding of deformation behavior and failure mechanisms in lead-free solder joints.

The present work investigates the effect of $\mathrm{Al}$ on the interfacial IMC between SAC105 solder alloy and copper substrate. This work concentrates on the effect of the lower percentage of $\mathrm{Al}(0.1-0.5 \mathrm{wt} . \%)$ 
on the $\mathrm{Cu}-\mathrm{Sn}$ reaction during reflow and isothermal aging. As has been noted earlier $[15,16]$, absence of $\mathrm{Cu}$ in the solder led to the formation of $\mathrm{Al}_{2} \mathrm{Cu}$ and $\mathrm{Al}-\mathrm{Cu}$ IMC near/at the interface during reflow, and the IMCs tended to spall away from the solder matrix when $\mathrm{Al}$ was depleted in solder, thus complicating the situation at the interface. With the presence of $\mathrm{Cu}$ in SAC solder, it is expected that $\mathrm{Al}$ will react with $\mathrm{Cu}$ in the bulk and thus provide a more simplified scenario at the interface, which may lead to a better understanding of the effects of Al. This study concentrates on the lower percentage of $\mathrm{Al}(0.1 \%-0.5 \%)$, as higher percentages may lead to formation of $\mathrm{Al}_{2} \mathrm{Cu}$ and other IMCs at the interface. Furthermore, this study investigates the nanomechanical properties of $\mathrm{Cu}$-Al IMC particles and also examines whether addition of $\mathrm{Al}$ would affect the nanomechanical properties of $\mathrm{Cu}_{6} \mathrm{Sn}_{5}$.

\section{Results}

\subsection{Differential Scanning Calorimetry}

Figure 1 shows the Differential Scanning Calorimetry (DSC) curves for SAC105, SAC105 + 0.1Al, SAC105 + 0.3Al and SAC105 + 0.5Al. During heating, SAC105 and SAC105+0.1Al solder show an onset melting temperature $\left(\mathrm{T}_{\mathrm{m}}\right)$ of $216.84{ }^{\circ} \mathrm{C} \pm 0.50$ and $216.43{ }^{\circ} \mathrm{C} \pm 0.38$, respectively. This onset temperature corresponds to the ternary eutectic reaction $\left(\mathrm{T}_{\mathrm{m}}=217^{\circ} \mathrm{C}\right)$ of $\mathrm{Sn}-\mathrm{Ag}$-Cu alloy, $\mathrm{L} \rightarrow \mathrm{Ag}_{3} \mathrm{Sn}+\mathrm{Cu}_{6} \mathrm{Sn}_{5}+\mathrm{Sn}$ [23]. Two prominent peaks were seen at $\sim 221^{\circ} \mathrm{C}$ and $\sim 228^{\circ} \mathrm{C}$ in SAC105 and SAC105 $+0.1 \mathrm{Al}$ (Figure 1a,b). These two peaks were associated with the eutectic temperature for $\mathrm{Sn}-\mathrm{Ag}\left(\mathrm{L} \rightarrow \mathrm{Ag}_{3} \mathrm{Sn}+\mathrm{Sn}\right)$ and $\mathrm{Sn}-\mathrm{Cu}\left(\mathrm{L} \rightarrow \mathrm{Cu}_{6} \mathrm{Sn}_{5}+\mathrm{Sn}\right)$, respectively. As the amount of $\mathrm{Al}$ was added up to $0.3 \mathrm{wt} . \%$, there is a change in the DSC curve (Figure 1c). The onset temperature was shifted to $221.14{ }^{\circ} \mathrm{C} \pm 0.36$ and $221.65^{\circ} \mathrm{C} \pm 1.02$, respectively for SAC105 $+0.3 \mathrm{Al}$ and SAC105 + 0.5Al which corresponded to Sn-Ag eutectic temperature $\left(\mathrm{T}_{\mathrm{m}}=221^{\circ} \mathrm{C}\right)$. For SAC105 $+0.3 \mathrm{Al}$, a first small peak of heat absorption appears at $224^{\circ} \mathrm{C}$, followed by a second larger peak of heat absorption at $\sim 231^{\circ} \mathrm{C}$ (Figure 1c). For SAC105 $+0.5 \mathrm{Al}$, only a large peak of heat absorption appears at $\sim 231^{\circ} \mathrm{C}$ (Figure 1d). The peak at $\sim 231^{\circ} \mathrm{C}$ corresponds to the melting temperature of $\mathrm{Sn}\left(\mathrm{T}_{\mathrm{m}}=231^{\circ} \mathrm{C}\right)$.

During cooling, the nucleation temperature was determined by the onset solidification of the exothermic peak (Figure 1b). SAC105 has an onset solidification at $200.12 \pm 0.64{ }^{\circ} \mathrm{C}$. Addition of aluminum to SAC105 shifted the exothermic peak to the right, where the onset solidification temperature is $215.84{ }^{\circ} \mathrm{C} \pm 1.39,217.74{ }^{\circ} \mathrm{C} \pm 0.83$ and $219.17{ }^{\circ} \mathrm{C} \pm 0.21$ for SAC105 $+0.1 \mathrm{Al}$, $\mathrm{SAC} 105+0.3 \mathrm{Al}$ and SAC105 $+0.5 \mathrm{Al}$, respectively.

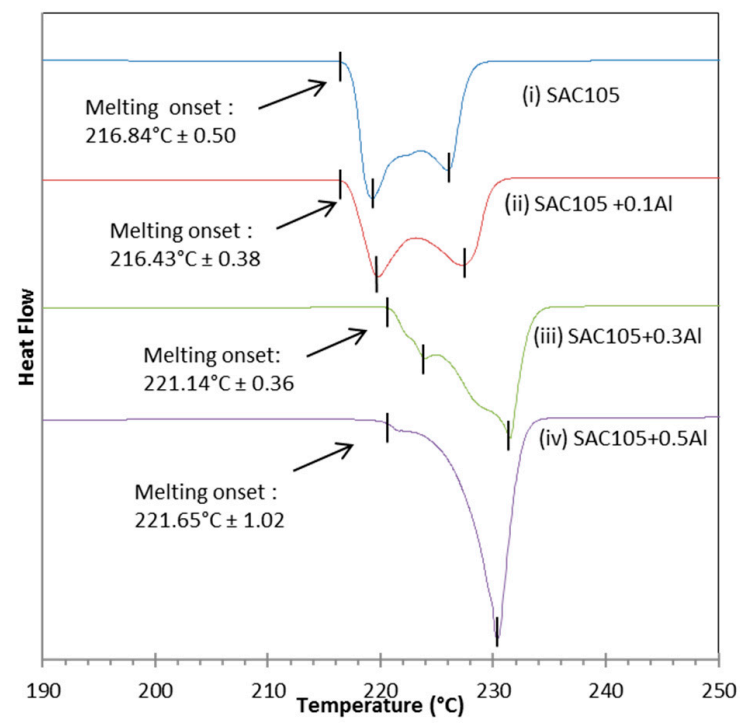

(a)

Figure 1. Cont. 


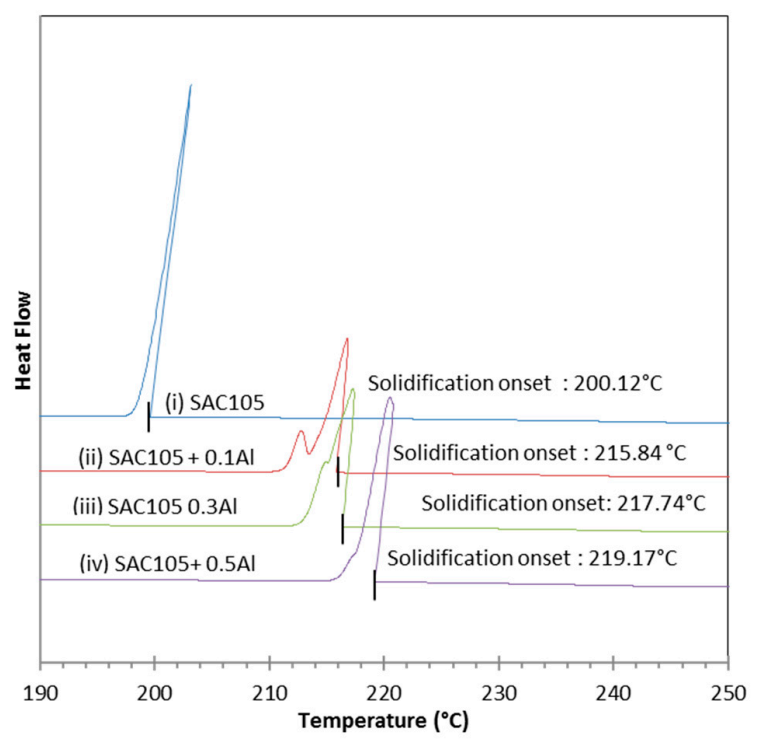

(b)

Figure 1. DSC curves for as cast SAC105, SAC105 + 0.1Al, SAC105 + 0.3Al and SAC105 + 0.5Al alloys: (a) heating; and (b) cooling.

The degree of undercooling, $\Delta \mathrm{T}$, was defined by the difference of two onset temperatures in cooling and heating curve. In Table 1, it can be seen that SAC105 has the largest undercooling of $\sim 17^{\circ} \mathrm{C}$. The addition of Al into SAC105 solder reduced the degree of undercooling significantly in all cases where $\mathrm{Al}$ was added.

Table 1. Onset of melting, onset of solidification and undercooling of SAC105, SAC105 + 0.1Al, $\mathrm{SAC} 105+0.3 \mathrm{Al}$ and SAC105 $+0.5 \mathrm{Al}$.

\begin{tabular}{cccc}
\hline Solder & Onset of Melting $\left({ }^{\circ} \mathbf{C}\right)$ & Onset of Solidification $\left({ }^{\circ} \mathbf{C}\right)$ & Undercooling $\left({ }^{\circ} \mathbf{C}\right)$ \\
\hline SAC105 & $216.84 \pm 0.50$ & $200.12 \pm 0.64$ & $\sim 17$ \\
SAC105 $+0.1 \mathrm{Al}$ & $216.43 \pm 0.38$ & $215.84 \pm 1.39$ & $\sim 0.6$ \\
SAC105 $+0.3 \mathrm{Al}$ & $221.14 \pm 0.36$ & $217.74 \pm 0.83$ & $\sim 3.4$ \\
SAC105 $+0.5 \mathrm{Al}$ & $221.65 \pm 1.02$ & $219.17 \pm 0.21$ & $\sim 2.48$ \\
\hline
\end{tabular}

\subsection{Microstructure}

Figure $2 \mathrm{a}-\mathrm{h}$ shows the cross sectional Scanning Electron Microscopy (SEM) images of as-received solder alloys and reflowed solder joints prepared on copper substrates. Cross sectional images of as-received SAC105 samples show primary Sn phase having a lighter contrast while the darker contrast phase represents $\mathrm{Cu}_{6} \mathrm{Sn}_{5}$. The $\mathrm{Cu}_{6} \mathrm{Sn}_{5}$ formed a continuous network in the as-cast SAC105 solder and fine $\mathrm{Ag}_{3} \mathrm{Sn}$ particles are also seen in the as-cast solder. With the addition of $0.1 \mathrm{wt} . \% \mathrm{Al}_{1} \mathrm{Cu}_{6} \mathrm{Sn}_{5}$ phase and particles of another new darker phase are seen distributed in the lighter contrast Sn phase. The darker particles are seen to agglomerate in the Sn phase (Figure $2 b$ ). With the addition of $0.3 \mathrm{wt} . \%$ and $0.5 \mathrm{wt} . \% \mathrm{Al}$, elongated shapes of new darker IMC phase are seen distributed in the lighter contrast $\mathrm{Sn}$ phase. It can be seen that the Sn grain size decreases with $\mathrm{Al}$ addition in the as-received alloys. After reflow, the bulk microstructure of the reflowed solder was different from that of the as-received solder. From Figure 2e,f it can be seen that $\mathrm{Cu}_{6} \mathrm{Sn}_{5}$ and $\mathrm{Ag}_{3} \mathrm{Sn}$ particles are larger after $1 \times$ reflow as compared to Figure $2 a, b$. After $1 \times$ reflow, with the addition of $0.3 \mathrm{wt} . \%$ and $0.5 \mathrm{wt}$. \% Al, equiaxed darker IMC was seen distributed in Sn phase instead of elongated shape of new darker IMC in the as-received sample. Sn grain size reduction as a function of Al content still persists in reflowed sample. 


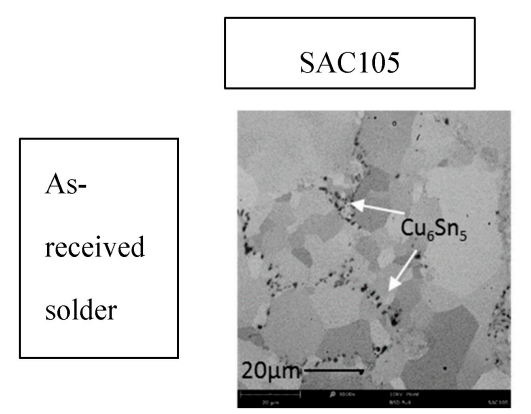

(a)

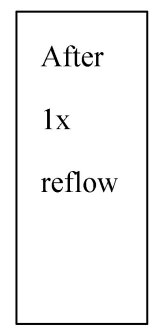

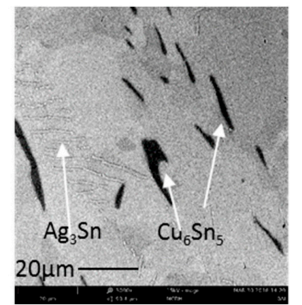

(e)

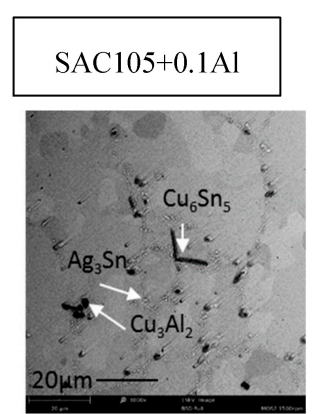

(b)

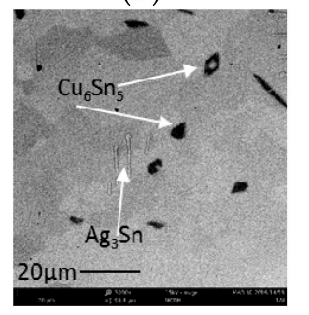

(f)

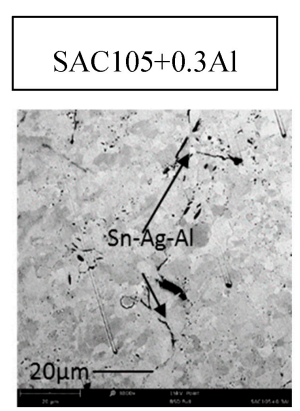

(c)

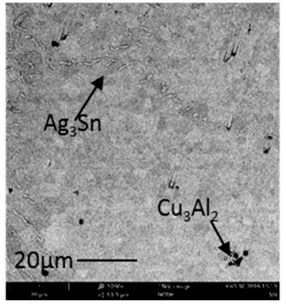

(g)

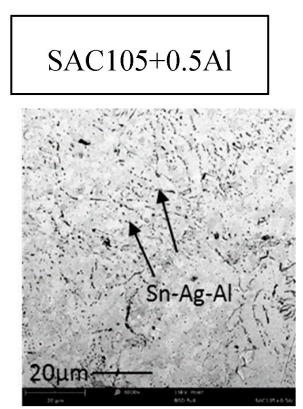

(d)

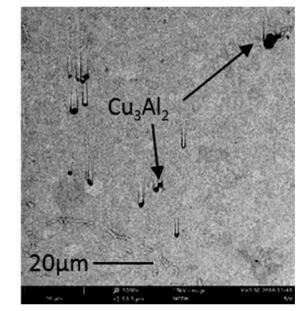

(h)

Figure 2. SEM images of cross sectional samples of bulk microstructure of as cast (a-d) and after $1 \times$ reflow $(\mathbf{e}-\mathbf{h})$ of SAC105, SAC105 + 0.1Al, SAC105 + 0.3Al and SAC105 + 0.5Al.

Figure 3a shows the optical microscope cross-sectional images of SAC105 + 0.5Al near top surface of solder after $1 \times$ reflow. It can be seen that the new darker phase equiaxed IMC agglomerated and was mostly found near the top surface of the solder joint. Agglomeration of the new darker phase near the top surface of solder is also found SAC105 + 0.3Al. Figure 3b shows the new darker phase equiaxed IMC under high magnification. It can be seen that the new faceted IMC particles have varied sizes, ranging from 1 to $5 \mu \mathrm{m}$.

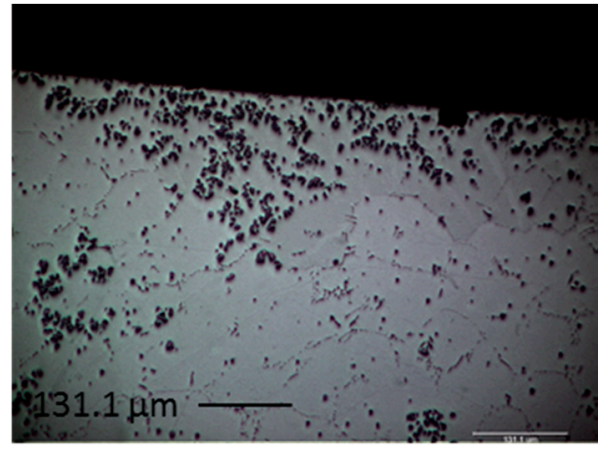

(a)

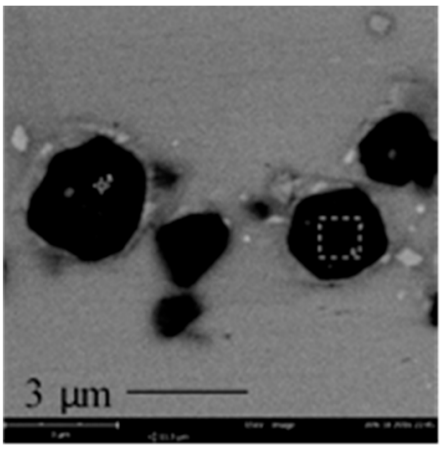

(b)

Figure 3. (a) Optical microscope cross sectional images SAC105 + 0.5Al near top surface of the solder after $1 \times$ reflow and (b) FESEM images of equiaxed but faceted IMCs found at cross-sectioned of SAC105 + 0.5Al.

Energy-dispersive X-ray Spectroscopic (EDS) analysis was conducted on the new IMC phase found in SAC105 + 0.1Al, SAC105 + 0.3Al and SAC105+0.5Al. Analysis results indicated that the composition of the new phase was 60-65 at.\% Cu, 35-40 at.\% Al. EDS Line scan and elemental mapping analysis were also conducted on the new IMC phase (Figures 4 and 5). Both analysis confirmed that this darker IMC phase consists of only $\mathrm{Al}$ and $\mathrm{Cu}$. Based on the ratio of $\mathrm{Al}$ and $\mathrm{Cu}$ content, possible identification of this darker IMC phase is $\mathrm{Cu}_{3} \mathrm{Al}_{2}(\delta)$ or $\mathrm{Cu}_{9} \mathrm{Al}_{4}\left(\gamma_{1}\right)$, both of which could exist in the temperature range below $300{ }^{\circ} \mathrm{C}[24]$. 

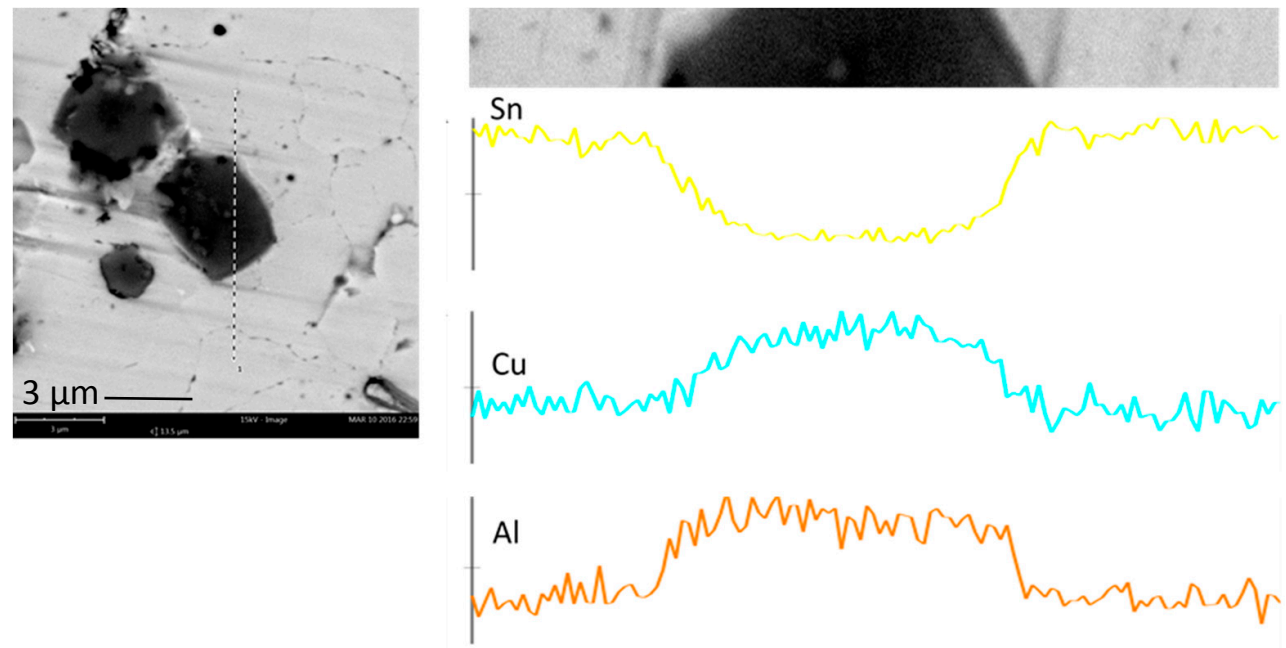

Figure 4. EDS line scan across equiaxed IMCs in SAC105 + 0.5Al.

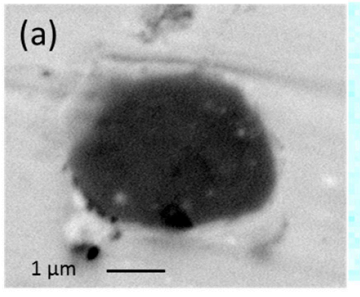

(d) Sn (b) Al

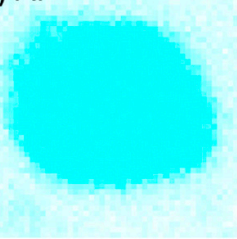

(c) $\mathrm{Cu}$

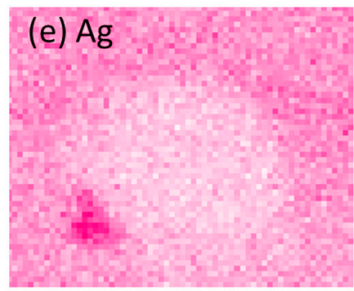

Figure 5. (a) Cross-sectioned image of $\mathrm{SAC} 105+0.5 \mathrm{Al}$ after $1 \times$ reflow. Elemental maps for the constituent elements: (b) $\mathrm{Al}$; (c) Cu; (d) Sn; and (e) Ag.

In the previous studies on minor addition of $\mathrm{Al}$, many researchers attempted to identify $\mathrm{Cu}-\mathrm{Al}$ IMC by EDS analysis. There are a few $\mathrm{Cu}-\mathrm{Al}$ binary phases that have compositions close to each other, such as $\gamma_{1}-\mathrm{Cu}_{9} \mathrm{Al}_{4}, \zeta_{2}-\mathrm{Cu}_{4} \mathrm{Al}_{3}$, and $\delta-\mathrm{Cu}_{3} \mathrm{Al}_{2}$. This makes it difficult for researchers to accurately identify the exact $\mathrm{Cu}-\mathrm{Al}$ phase form $[2,17,20]$. Similarly, in this study, EDX analysis could not provide clear identification for the $\mathrm{Cu}-\mathrm{Al}$ compound. Anderson et al. who studied the effect of $\mathrm{Al}$ addition on the microstructure of solder have identified the $\mathrm{Cu}-\mathrm{Al} \mathrm{IMC}$ as $\delta-\mathrm{Cu}_{33} \mathrm{Al}_{17}$. They did so by casting out a $\mathrm{Cu}$-Al block which has the similar composition with the $\mathrm{Cu}$-Al IMC they obtained in the bulk solder, and analyzed it using X-ray diffraction (XRD) [14]. Though Anderson et al. have chosen to refer to it as $\delta-\mathrm{Cu}_{33} \mathrm{Al}_{17}$, the general nomenclature for these IMC is also known as $\delta-\mathrm{Cu}_{3} \mathrm{Al}_{2}$ [24]. By comparing the morphology of $\mathrm{Cu}-\mathrm{Al} \mathrm{IMC}$ (Figure 3a) in this study to $\delta-\mathrm{Cu}_{33} \mathrm{Al}_{17}$ [14], it can be seen that they both exhibit a similar morphology (equiaxed and faceted dark color appearance under Field-emission scanning electron microscopy (FESEM) and size (size varied from 1 to $5 \mu \mathrm{m}$ )). Thus, it would be logical to assume both IMC are of the same kind, and it will be referred to as $\mathrm{Cu}_{3} \mathrm{Al}_{2}$ in the following discussion.

\subsection{Interfacial Reaction after Reflow}

Figure 6 shows cross-sectional FESEM micrographs at the solder/Cu interface after $1 \times$ reflow. A typical scallop type $\mathrm{Cu}_{6} \mathrm{Sn}_{5}$ layer forms at the SAC105/Cu interface after reflow (Figure 6a). Upon the addition of aluminum, the scallop morphology is still seen, but the IMC becomes more flat as $\mathrm{Al}$ is 
added up to 0.5 wt.\% (Figure 6c). The IMC height is reduced with the addition of Al. The average thickness of the total IMC layer is plotted as a function of $\mathrm{Al}$ content in Figure 7. The influence of $\mathrm{Al}$ addition on the interfacial IMC thickness is obvious. The thickness of the interfacial IMC does not seem to vary with the $\mathrm{Al}$ content of the solder in the range $0.1-0.5 \mathrm{wt} . \%$. This may indicate that the addition of $\mathrm{Al}$ beyond a certain percentage does not bring additional benefit in terms of suppression of IMC growth. $\mathrm{Cu}_{6} \mathrm{Sn}_{5}$ was the only IMC found at the interface, and no trace of $\mathrm{Al}$ in $\mathrm{Cu}_{6} \mathrm{Sn}_{5}$ and $\mathrm{Al}-\mathrm{Cu}$ compound could be detected at the interface of all aluminum-added solder.

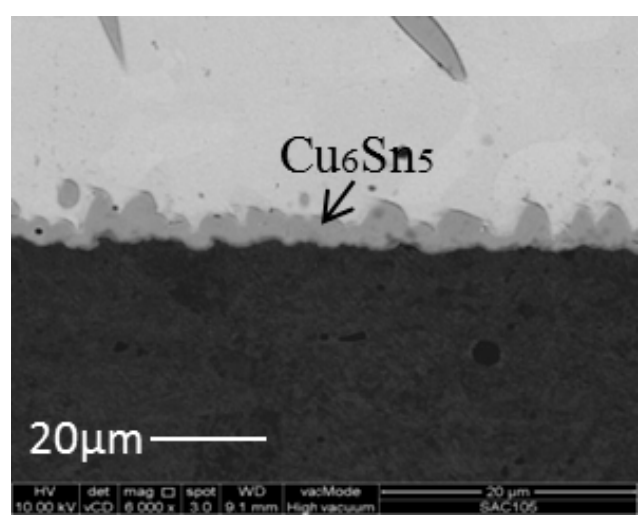

(a)

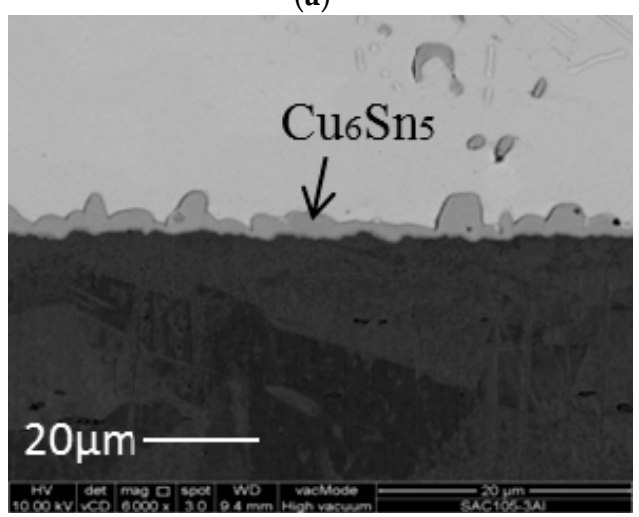

(c)

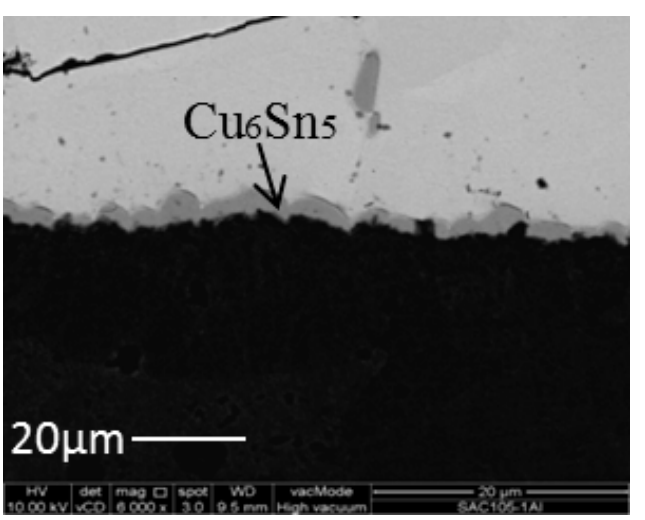

(b)

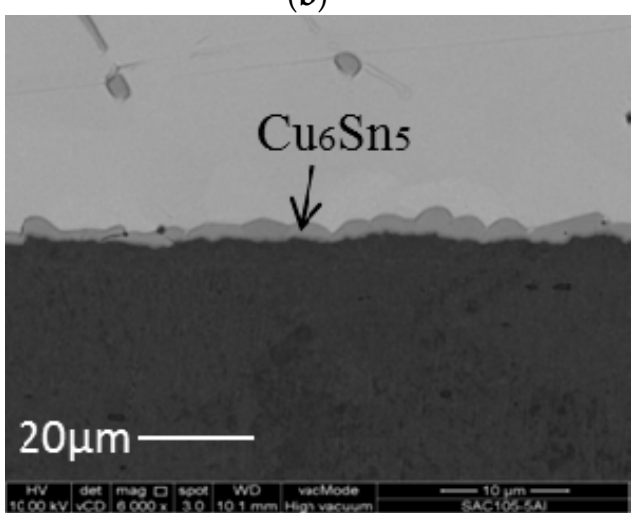

(d)

Figure 6. Cross sectional FESEM micrographs of: (a) SAC105; (b) SAC105 + 0.1Al; (c) SAC105 + 0.3Al; and (d) SAC105 $+0.5 \mathrm{Al}$ after $1 \times$ reflow.

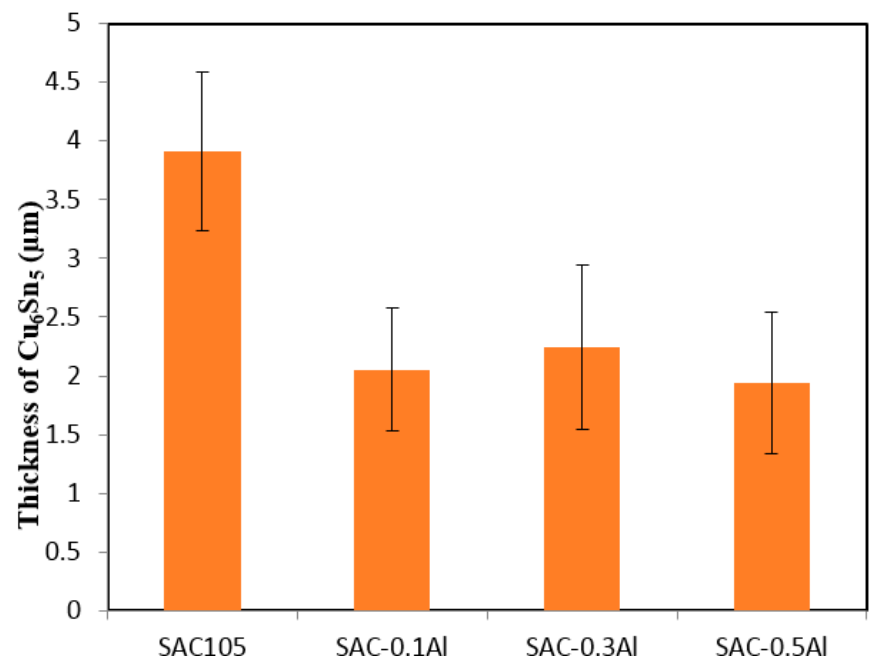

Figure 7. Variation of $\mathrm{Cu}_{6} \mathrm{Sn}_{5}$ thickness with $\mathrm{Al}$ content during $1 \times$ reflow. 


\subsection{Top View of $\mathrm{Cu}_{6} \mathrm{Sn}_{5}$ Solder after $1 \times$ Reflow}

Figure 8a shows top view image of deeply etched SAC105 $+0.5 \mathrm{Al}$ after $1 \times$ reflow. Prior to FESEM imaging, both samples were deeply etched in a mixture of $93 \% \mathrm{CH}_{3} \mathrm{OH}, 5 \% \mathrm{HNO}_{3}$ and $2 \%$ $\mathrm{HCl}$ to remove the solder matrix and thereby expose the interfacial IMC. The IMC grains found on the interface of SAC105 and SAC105 $+0.5 \mathrm{Al}$ were identified as $\mathrm{Cu}_{6} \mathrm{Sn}_{5}$. It can be seen from the images that $\mathrm{SAC} 105+0.5 \mathrm{Al}$ shows somewhat faceted $\mathrm{Cu}_{6} \mathrm{Sn}_{5}$ grains. Under high magnification in the high $\mathrm{Al}$ concentration region, small and agglomerated particles are seen (encircled in yellow dotted line). EDS analysis was done on the high $\mathrm{Al}$ concentration particle. Figure $8 \mathrm{~b}-\mathrm{d}$ shows the EDS elemental maps. Under high resolution imaging and elemental mapping, $\mathrm{Al}, \mathrm{Ag}$ and $\mathrm{Cu}$ were detected on the surface of the exposed IMC. In Figure 8b, the presence of $\mathrm{Al}$ is indicated in green. The region of high concentration of $\mathrm{Al}$ is encircled in yellow. It can be seen that the region with high $\mathrm{Al}$ concentration corresponds to that of $\mathrm{Cu}$ (compare Figure 8b,c). The agglomerated particles are identical to the $\mathrm{Cu}-\mathrm{Al}$ IMC that was found in the bulk microstructure. The elongated and plate-like particles (right corner of Figure 8d) on the $\mathrm{Cu}_{6} \mathrm{Sn}_{5}$ IMC grains are identified as $\mathrm{Ag}_{3} \mathrm{Sn}$.

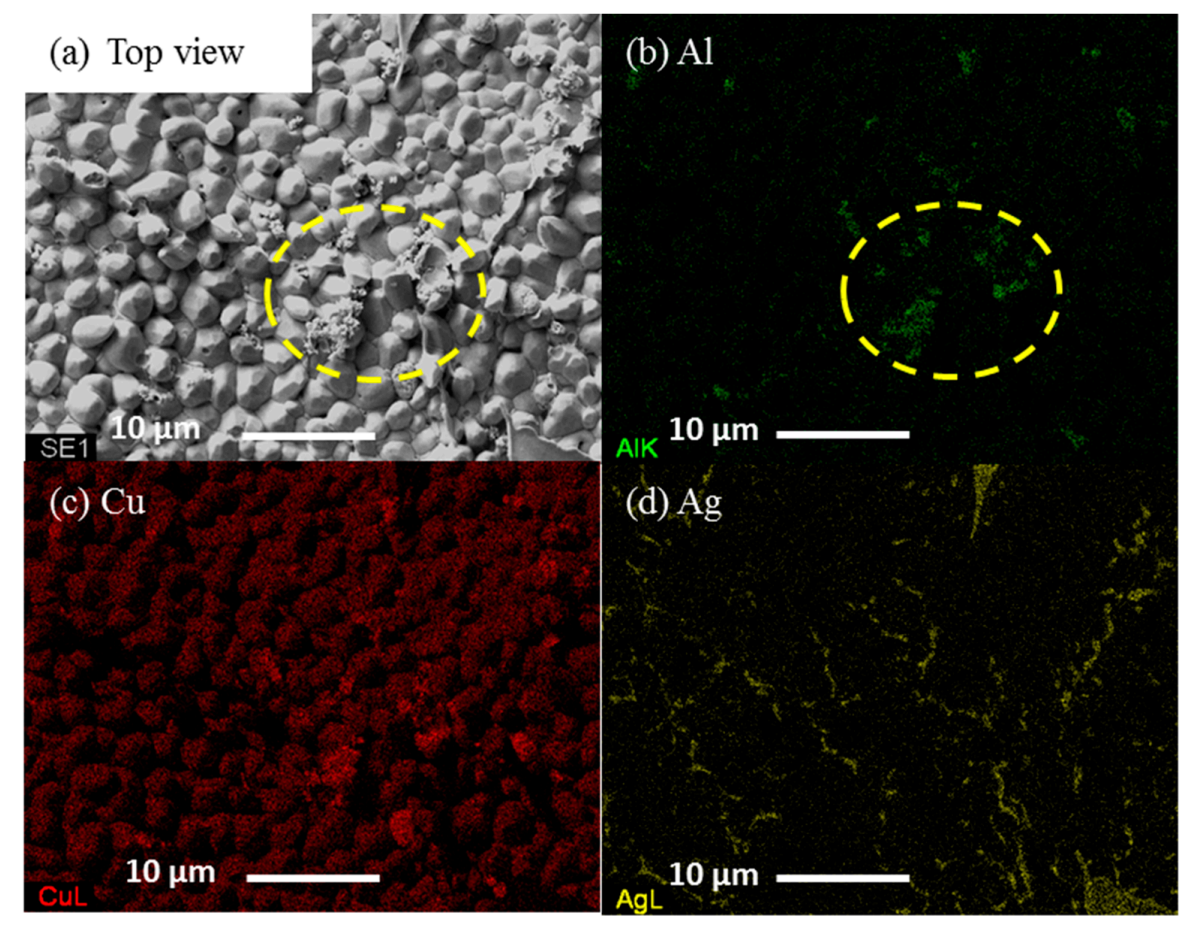

Figure 8. (a) Top view image of deeply etched SAC105 $+0.5 \mathrm{Al}$ after $1 \times$ reflow. Elemental maps for the constituent elements: (b) $\mathrm{Al}$; (c) Cu; and (d) Ag.

\subsection{Interfacial Reaction After Isothermal Aging}

After $1 \times$ reflow, some of the solder samples were also subjected to isothermal aging at $150{ }^{\circ} \mathrm{C}$ for up to $720 \mathrm{~h}$ in order to study the effects of $\mathrm{Al}$ addition on the solid state reaction between solder and copper substrate. Figure 9 shows the cross sectional images of isothermally aged SAC105, SAC105 + 0.1Al, SAC105 + 0.3Al and SAC105 + 0.5Al. After thermal aging for $720 \mathrm{~h}$, another intermetallic layer (darker layer) formed in between the first intermetallic layer and $\mathrm{Cu}$ substrate in both SAC and SAC + Al solders. EDS was used to determine the composition of each layer. It is confirmed by elemental ratio by EDS analysis that the outer layer is $\mathrm{Cu}_{6} \mathrm{Sn}_{5}$ and the inner layer is $\mathrm{Cu}_{3} \mathrm{Sn}$. Within the resolution of EDS, there was no aluminum detected in both $\mathrm{Cu}_{6} \mathrm{Sn}_{5}$ and $\mathrm{Cu}_{3} \mathrm{Sn}$ after thermal aging. The morphology of $\mathrm{Cu}_{6} \mathrm{Sn}_{5}$ and $\mathrm{Cu}_{3} \mathrm{Sn}$ are seen to be similar in SAC105 and SAC105 + Al solders. 


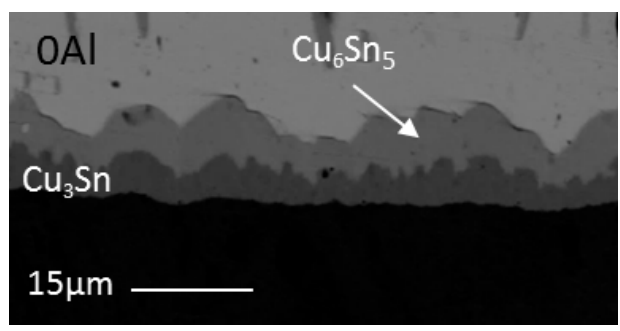

(a)

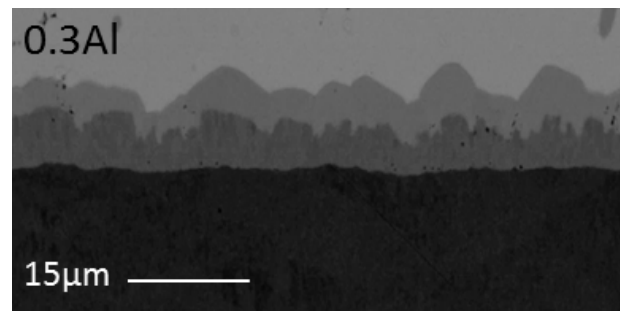

(c)

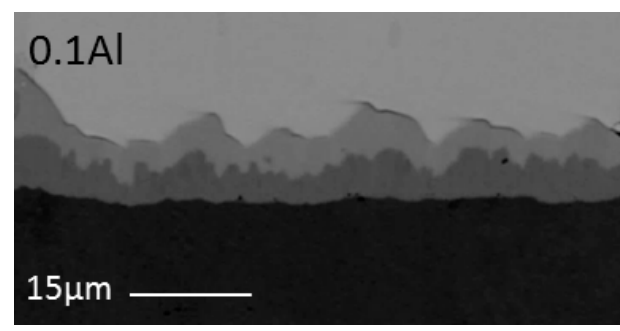

(b)

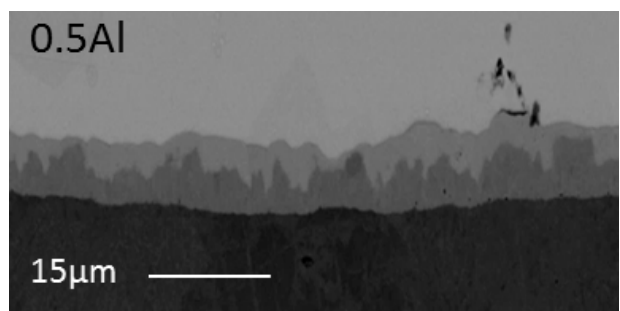

(d)

Figure 9. Cross sectional images of: (a) SAC105; (b) SAC105 + 0.1Al; (c) SAC105 + 0.3Al; and (d) SAC105 $+0.5 \mathrm{Al}$ after aging at $150{ }^{\circ} \mathrm{C}$ for $720 \mathrm{~h}$.

From Figure 9, it is seen that the addition of $\mathrm{Al}$ up to $0.5 \mathrm{wt} . \%$ has slowed down the growth of the total interfacial IMCs. Figure 10 shows the thickness of $\mathrm{Cu}_{6} \mathrm{Sn}_{5}$ and $\mathrm{Cu}_{3} \mathrm{Sn}$ plotted as a function of $\mathrm{Al}$ content. It can be seen that $\mathrm{Cu}_{6} \mathrm{Sn}_{5}$ is reduced as $\mathrm{Al}$ is added, up to $0.5 \mathrm{wt}$.\%. However, the thickness of $\mathrm{Cu}_{3} \mathrm{Sn}$ is almost the same for all samples.

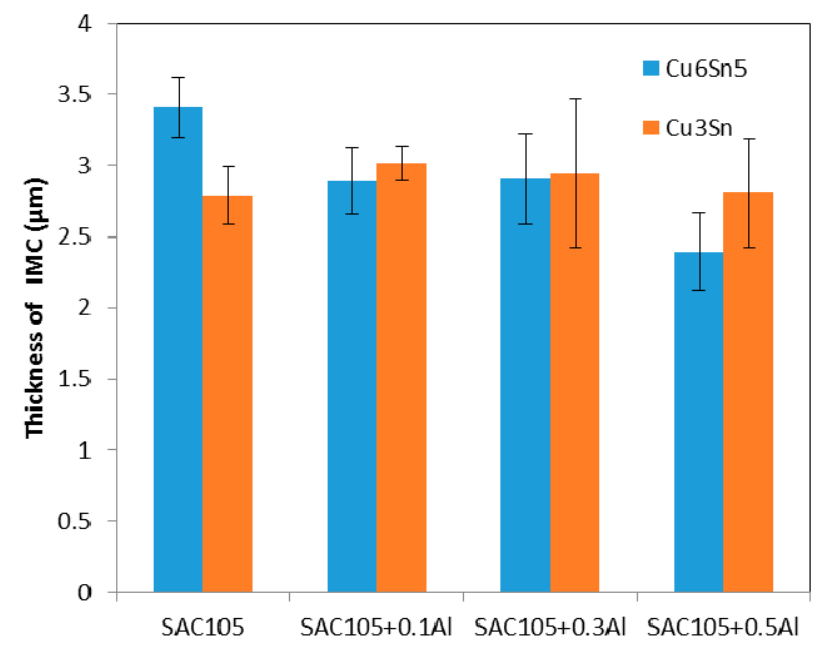

Figure 10. Variation of thickness of IMC with $\mathrm{Al}$ content after aging at $150{ }^{\circ} \mathrm{C}$ for $720 \mathrm{~h}$.

\subsection{Mechanical Properties}

Indentation testing was carried out on bulk solder and the intermetallic phase in the solders, e.g., $\mathrm{Cu}_{6} \mathrm{Sn}_{5}$ and $\mathrm{Cu}_{3} \mathrm{Al}_{2}$. The hardness of the bulk solder was determined by Vickers hardness test while the hardness of individual intermetallic phase was determined by nanoindentation. Figure 11 shows the hardness of solder with varying Al content. It can be seen that the hardness of the solder increases as a function of Al content. SAC105 exhibited hardness of $9.78 \mathrm{HV}$ while SAC105 + 0.5Al exhibited the highest hardness value of $14.12 \mathrm{HV}$. The result of SAC105 is in good agreement with other studies $[25,26]$. 


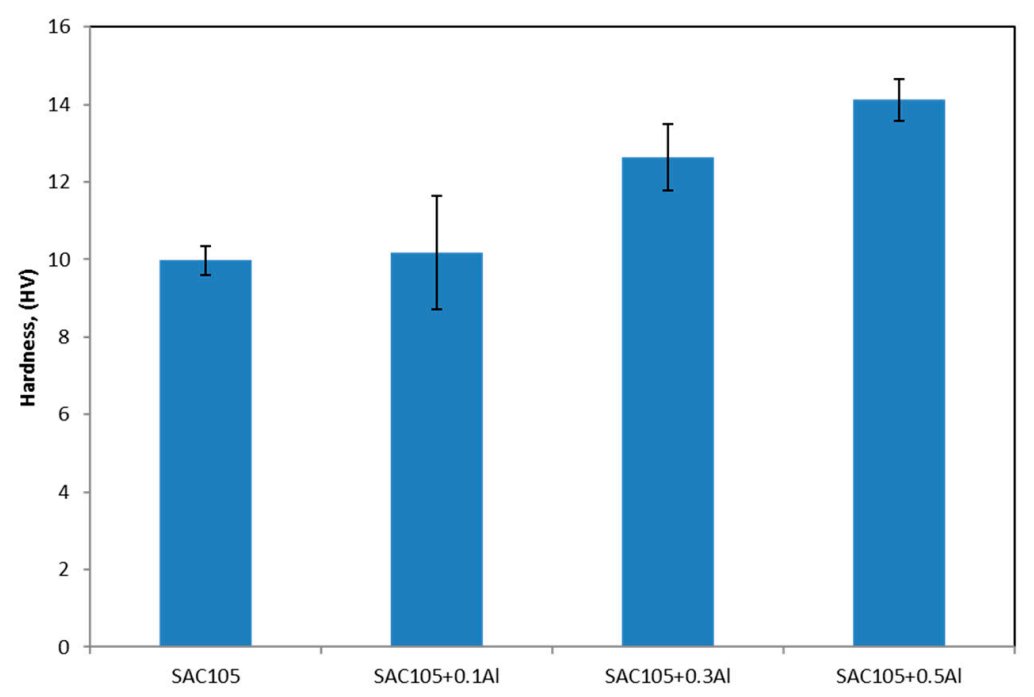

Figure 11. Variation of Vickers hardness with $\mathrm{Al}$ content for as received samples.

Figure 12 shows typical load displacement data obtained through indentations performed on Sn, $\mathrm{Cu}_{6} \mathrm{Sn}_{5}$ and $\mathrm{Cu}_{3} \mathrm{Al}_{2}$ of a maximum load of $500 \mu \mathrm{N}$. For a test of the same maximum load, the maximum penetration of the indenter for $\mathrm{Sn}-\mathrm{Ag}$-Cu solder is approximately 4.5 times of that measured for $\mathrm{Cu}_{6} \mathrm{Sn}_{5}$ and $\mathrm{Al}_{3} \mathrm{Cu}_{2}$. The solder matrix, as expected, is very soft, with a hardness of $0.23-0.3 \mathrm{GPa}$. The matrix exhibited significant plasticity. Upon unloading, the solder recovers only approximately $10 \mathrm{~nm}$ of the $230 \mathrm{~nm}$ that the indenter penetrated. In contrast to the solder, both intermetallics are significantly harder: $\mathrm{Cu}_{6} \mathrm{Sn}_{5}(\sim 6.2 \mathrm{GPa})$ and $\mathrm{Al}_{3} \mathrm{Cu}_{2}(\sim 10.50 \mathrm{GPa})$. The intermetallics typically recover around $40 \%$ of the maximum penetration of the indenter upon unloading. From this, the deformation of the intermetallic phases was found to be both elastic and plastic, while the deformation of the solder is found to be primarily plastic [26]. Scanning probe microscopy (SPM) was used to accurately perform indentation on specific IMC phases. It was also used to observe the residual indents, as shown in Figure 13. As expected from the nanoindentation data in Figure 12, the residual indents in the solder were much larger than in intermetallics (Figure 13). All of the residual indents observed for the intermetallics exhibited a smooth profile with no detected pile-up or sink-in of material, while softer materials like Sn exhibit a pile-up behavior.

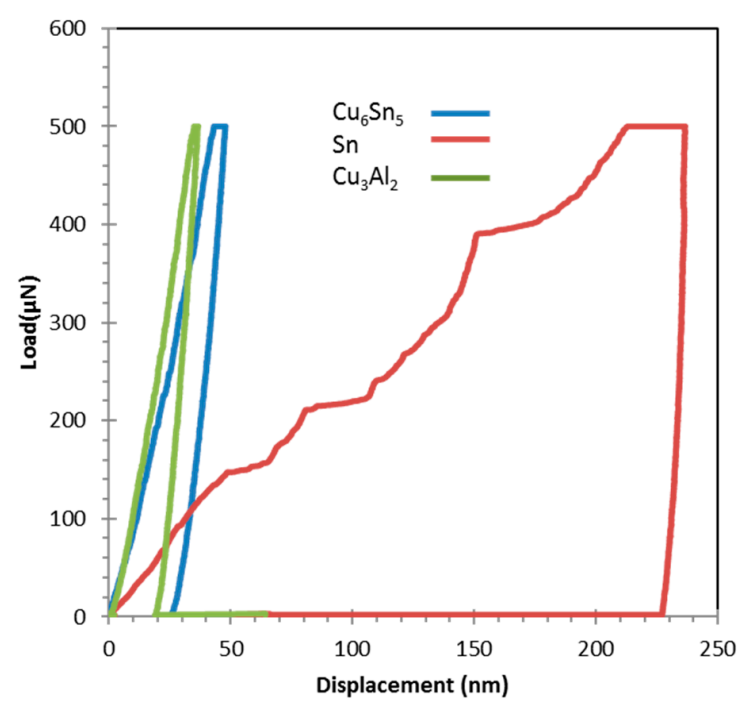

Figure 12. Load displacement data obtained for $500 \mu \mathrm{N}$ maximum load indentations performed on $\mathrm{Sn}$, $\mathrm{Cu}_{6} \mathrm{Sn}_{5}$ and $\mathrm{Cu}_{3} \mathrm{Sn}$. 


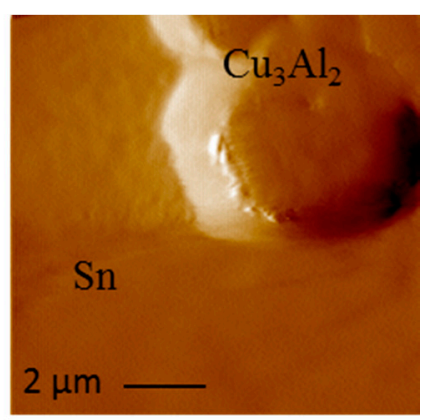

(a)

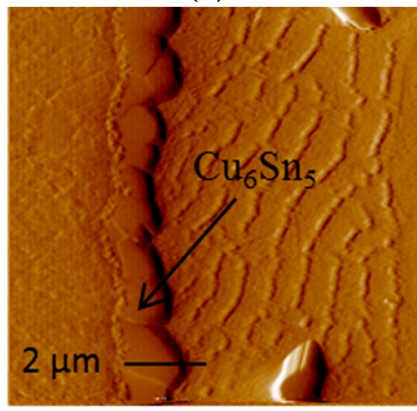

(c)

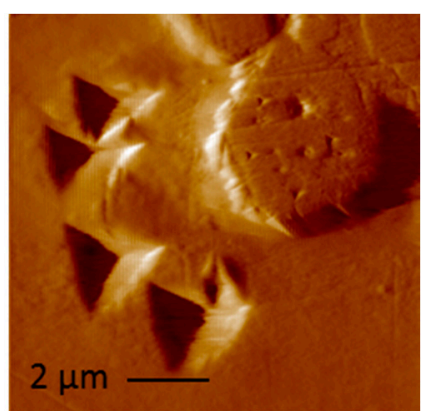

(b)

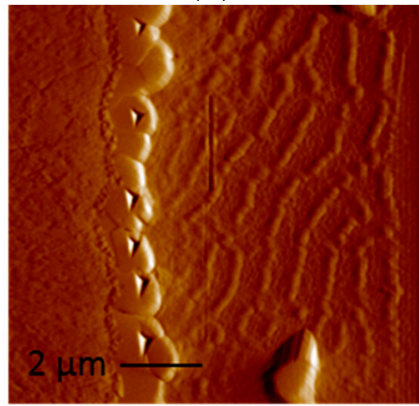

(d)

Figure 13. Scanning probe microscopy image of: (a) $\mathrm{Sn}$ and $\mathrm{Cu}_{3} \mathrm{Al}_{2}$ before indentation; (b) $\mathrm{Sn}$ and $\mathrm{Cu}_{3} \mathrm{Al}_{2}$ after indentation; (c) $\mathrm{Cu}_{6} \mathrm{Sn}_{5}$ before indentation; and (d) $\mathrm{Cu}_{6} \mathrm{Sn}_{5}$ after indentation of $\mathrm{SAC} 105+0.1 \mathrm{Al}$.

Hysitron nanoDMA with CMX correction and maximum load of $1000 \mu \mathrm{N}$ was used to perform continuous nanoscale dynamic mechanical measurement of $\mathrm{Cu}_{3} \mathrm{Al}_{2}$. Hardness and elastic modulus of $\mathrm{Cu}_{3} \mathrm{Al}_{2}$ could be obtained as a function of indentation depth. Figure 14 shows the hardness and elastic modulus of $\mathrm{Cu}_{3} \mathrm{Al}_{2}$ plotted against indent displacement. The hardness and elastic modulus of $\mathrm{Cu}_{3} \mathrm{Al}_{2}$ was lower near the surface but was fairly constant at depths greater than $\sim 15 \mathrm{~nm}$. The results are similar to that obtained from quasi-static measurement with maximum load of $500 \mu \mathrm{N}$.

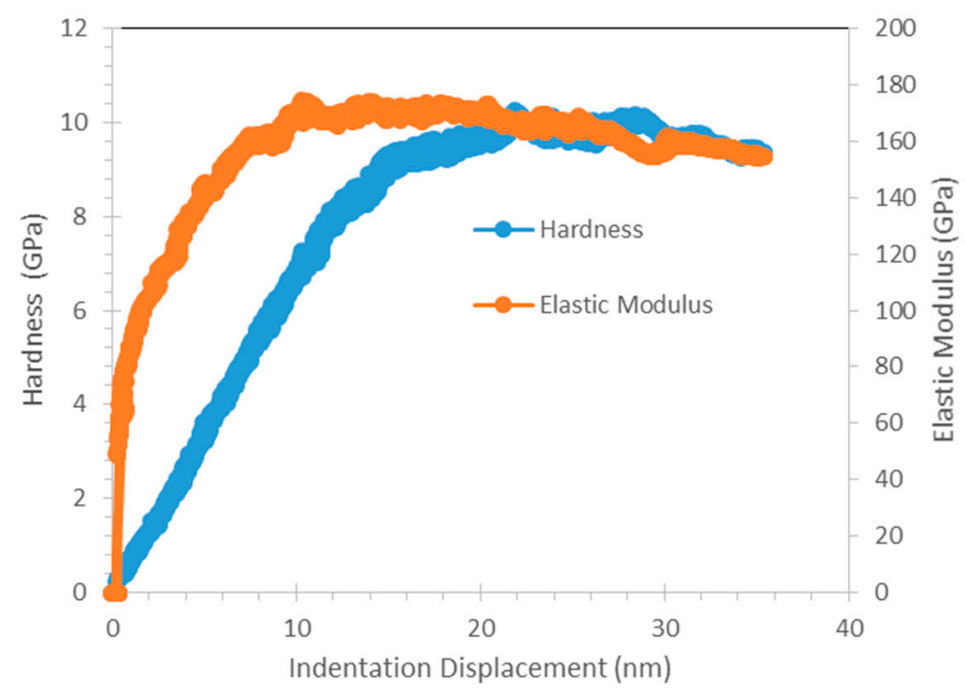

Figure 14. Hardness and Elastic Modulus of $\mathrm{Cu}_{3} \mathrm{Al}_{2}$ plotted against indent displacement.

As seen in Table 2, Sn has hardness and elastic modulus of 0.22-0.36 GPa and $~ 50 \mathrm{GPa}$, respectively, while $\mathrm{Cu}_{6} \mathrm{Sn}_{5}$ has hardness and elastic modulus of $\sim 6.2 \mathrm{GPa}$ and $\sim 92-110 \mathrm{GPa}$, respectively. The results 
are in good agreement with other studies [27-29]. On the other hand, $\mathrm{Cu}_{3} \mathrm{Al}_{2}$ exhibits a much higher hardness and elastic modulus as compared to $\mathrm{Sn}$ and $\mathrm{Cu}_{6} \mathrm{Sn}_{5}$, with a hardness of $\sim 10.50 \mathrm{GPa}$ and an elastic modulus of $170.08 \mathrm{GPa}$.

Table 2. Hardness and modulus of Pure $\mathrm{Sn}, \mathrm{Cu}_{6} \mathrm{Sn}_{5}$, and $\mathrm{Cu}_{3} \mathrm{Al}_{2}$.

\begin{tabular}{ccccc}
\hline \multirow{2}{*}{ Element/Compound } & \multicolumn{2}{c}{ SAC105 } & \multicolumn{2}{c}{ SAC + 0.1Al } \\
\cline { 2 - 5 } & E (GPa) & H (GPa) & E (GPa) & H (GPa) \\
\hline$S n$ & $49.43 \pm 7.93$ & $0.29 \pm 0.07$ & $50.43 \pm 4.86$ & $0.23 \pm 0.04$ \\
$\mathrm{Cu}_{6} \mathrm{Sn}_{5}$ & $92.25 \pm 16.24$ & $6.20 \pm 0.59$ & $100.99 \pm 10.09$ & $6.26 \pm 1.07$ \\
$\mathrm{Cu}_{3} \mathrm{Al}_{2}$ & - & - & $170.08 \pm 12.92$ & $10.52 \pm 1.71$ \\
\hline
\end{tabular}

\section{Discussion}

From the DSC curves (Figure 1), it is found that when $0.1 \mathrm{wt} . \%$ of $\mathrm{Al}$ was added to the solder, the endothermic curve remains similar to that of SAC105. Both SAC105 and SAC105 + 0.1Al exhibit twin peaks endothermic curve. The onset melting temperature of SAC105 + 0.1Al is the same as that of SAC105, which is $\sim 217^{\circ} \mathrm{C}$. This corresponds to Sn-Ag-Cu ternary eutectic temperature. When the percentage of $\mathrm{Al}$ is increased to $0.3 \mathrm{wt} . \%$ and $0.5 \mathrm{wt} . \%$, the onset of melting temperature shifts to $\sim 221^{\circ} \mathrm{C}$ (Sn-Ag eutectic temperature) [30]. The DSC curves of SAC105 + 0.3Al and SAC + 0.5Al solders are similar to the DSC curve of non-eutectic Sn-Ag solder [31]. This shows that free $\mathrm{Cu}$ atoms are not available in SAC105 + 0.3Al and SAC + 0.5Al solders as Sn-Ag-Cu solder alloy always shows the onset melting at $\sim 217^{\circ} \mathrm{C}$ [32]. One possible explanation for this is the formation of $\mathrm{Cu}_{3} \mathrm{Al}_{2}$ compound, which has reduced the available $\mathrm{Cu}$ in the bulk solder to react with $\mathrm{Sn}$ and $\mathrm{Ag}$. The $\mathrm{Cu}_{3} \mathrm{Al}_{2}$ compound already formed in the as-received samples, which were supplied in the as-cast condition. As seen in Figure $2 b-d, \mathrm{Cu}_{3} \mathrm{Al}_{2}$ is formed in the as-cast solder. $\mathrm{Cu}_{3} \mathrm{Al}_{2}$ has a higher melting temperature of $960{ }^{\circ} \mathrm{C}$ [33]. Thus, during the melting of solders for up to $300{ }^{\circ} \mathrm{C}$, the stable $\mathrm{Cu}_{3} \mathrm{Al}_{2} \mathrm{IMC}$ did not react and this lowers the activity of $\mathrm{Cu}$ in solder melts. The lack of free $\mathrm{Cu}$ atom in the solder is further indicated by the shift of a prominent peak in the DSC curves of SAC105 and SAC105 + 0.1Al. The $\sim 228^{\circ} \mathrm{C}$ (Sn-Cu eutectic temperature) peak in SAC105 and SAC105 + 0.5Al has shifted to $\sim 231^{\circ} \mathrm{C}$ $\left(\mathrm{T}_{\mathrm{m}}\right.$ of $\left.\mathrm{Sn}=232^{\circ} \mathrm{C}\right)$ in SAC105 $+0.3 \mathrm{Al}$ and SAC105 $+0.5 \mathrm{Al}$. This shift indicates that the deficiency of $\mathrm{Cu}$ atom in SAC105 + 0.3Al and SAC105 + 0.5Al has reduced the strong eutectic reaction of $\mathrm{Sn}-\mathrm{Cu}$, $\mathrm{L} \rightarrow \mathrm{Cu}_{6} \mathrm{Sn}_{5}+\mathrm{Sn}$. With $\mathrm{Al}$ addition, the peak indicating $\mathrm{Sn}$ melting is seen, as fractions of un-melted Sn remaining in the solder melted when temperature increased to $232^{\circ} \mathrm{C}$ [30].

Table 1 shows that SAC105 has the largest undercooling of $\sim 17^{\circ} \mathrm{C}$. This is well within range of undercooling values, $10-30^{\circ} \mathrm{C}$ reported for $\mathrm{Sn}-\mathrm{Ag}-\mathrm{Cu}$ solder [1]. This is because $\beta$-Sn requires large undercooling to induce nucleation and solidification [1]. The presence of Al in SAC105 has reduced the undercooling significantly. It is seen that with addition of $\mathrm{Al}$ up to $0.5 \%$, undercooling has reduced to $1-5{ }^{\circ} \mathrm{C}$. Kotadia et al. and Anderson et al. have observed the effect of $\mathrm{Al}$ in reducing undercooling of Sn-3.5Ag and Sn-3.5Ag-0.95Cu solder to $7{ }^{\circ} \mathrm{C}$ and $4{ }^{\circ} \mathrm{C}$ respectively [14,34]. The addition of minor alloying element into solder has been one of the effective ways of reducing undercooling by promoting nucleation of $\beta$-Sn. Minor alloying atoms which have a much higher melting temperature can exist in molten $\mathrm{Sn}$ and provide heterogeneous site for $\beta$-Sn nucleation. In the case of $\mathrm{Al}$ as minor alloying, $\mathrm{Cu}_{3} \mathrm{Al}_{2}$ compound is formed even when the addition of $\mathrm{Al}$ is as low as $0.1 \%$. During exothermic reaction in DSC, the existing $\mathrm{Al}-\mathrm{Cu}$ intermetallic compounds act as a preferential site to promote heterogeneous nucleation of $\beta-S n$, and thus lowering the undercooling of SAC105.

Segregated $\mathrm{Cu}_{3} \mathrm{Al}_{2} \mathrm{IMC}$ was found near the top surface of the sample with addition of $\mathrm{Al}$ after $1 \times$ reflow. One of the possible reasons could be that, during reflow, solders are melted on the $\mathrm{Cu}$ substrates at $250{ }^{\circ} \mathrm{C}$, the $\mathrm{Cu}_{3} \mathrm{Al}_{2}$ particles are not wet by the molten solder, thus they are not drawn into the melt as the molten solder particles solidify. This causes rejection of the $\mathrm{Cu}_{3} \mathrm{Al}_{2}$, which remain near the surface/edges of the solder after reflow. Another possible reason for the segregation of 
$\mathrm{Cu}_{3} \mathrm{Al}_{2}$ particles at the edge/surface could be attributed to the buoyancy effects. The density of $\mathrm{Cu}_{3} \mathrm{Al}_{2}$ particles is $6.278 \mathrm{~g} / \mathrm{cm}^{3}$, which is lower than the density of liquid $\mathrm{Sn}, 6.99 \mathrm{~g} / \mathrm{cm}^{3}$ [35]. Thus, during reflow, the less dense $\mathrm{Cu}_{3} \mathrm{Al}_{2}$ particles migrate to the surface/edges. Kotadia et al. have reported the segregation of $\mathrm{Al}_{2} \mathrm{Cu}$ in $\mathrm{SA}$ solder. They suggested that the segregation of $\mathrm{Al}$ rich phase and $\mathrm{Al}-\mathrm{Cu}$ compound is caused by Stokes and Marangoi motion, which is due to large stable liquid miscibility gap in binary $\mathrm{Sn}-\mathrm{Al}$ and ternary $\mathrm{Sn}-\mathrm{Ag}-\mathrm{Al}[18]$.

Minor alloying elements which could affect the growth of $\mathrm{Cu}-\mathrm{Sn}$ compound are divided into two categories: (i) elements that show marked solubility in either one or both of the Cu-Sn IMCs; and (ii) elements that do not significantly dissolve in either of the $\mathrm{Cu}-\mathrm{Sn}$ IMCs [11]. The effect of elements in category 1 on IMC growth could be explained by using thermodynamic argument. These elements stabilize $\mathrm{Cu}_{6} \mathrm{Sn}_{5}$ and decrease the growth of $\mathrm{Cu}_{3} \mathrm{Sn}$. The elements in category 2 do not have a prominent effect on IMC as they only affect the growth of IMC layers indirectly. It can be seen from Figures 4 and 5 that the addition of $\mathrm{Al}$ has reduced the growth of $\mathrm{Cu}_{6} \mathrm{Sn}_{5}$. Though Anderson et al. have suggested $\mathrm{Al}$ has some solubility in $\mathrm{Cu}_{6} \mathrm{Sn}_{5}$, no trace of $\mathrm{Al}$ could be found in $\mathrm{Cu}_{6} \mathrm{Sn}_{5}$ in this study. In this study, the addition of up to $0.5 \mathrm{wt} . \% \mathrm{Al}$ did not alter the scallop morphology of $\mathrm{Cu}_{6} \mathrm{Sn}_{5}$ [14]. Scallop type IMC formation is promoted by higher value of the IMC/liquid solder interfacial energy.

There is very limited amount of information available on the influence of $\mathrm{Al}$ on the $\mathrm{Cu}-\mathrm{Sn}$ reaction. $\mathrm{Li}$ et al. have reported the suppression of $\mathrm{Cu}_{6} \mathrm{Sn}_{5} \mathrm{IMC}$ growth with addition of $1 \% \mathrm{Al}$. They suggested that the suppression is due to the formation of an Al-Cu IMC layer at the interface, which acts as a barrier for $\mathrm{Cu}$ and $\mathrm{Sn}$ diffusion [16]. However, Al-Cu IMC layer is not found at the interface in this study as the amount of $\mathrm{Al}$ added is less $(\leqslant 5 \%)$. Dhaffer et al. have also reported suppression of $\mathrm{Cu}_{6} \mathrm{Sn}_{5}$ IMC growth with addition of $0.1 \% \mathrm{Al}$ during dip soldering and solid state reaction [20]. $\mathrm{The}^{\mathrm{Cu}} \mathrm{Al}_{2}$ IMC found at the $\mathrm{Cu}_{6} \mathrm{Sn}_{5} / \mathrm{Sn}$ interface (Figure 8) could account for the suppression of $\mathrm{Cu}_{6} \mathrm{Sn}_{5}$. This is seen in previous work where $\mathrm{Zn}$ found at the $\mathrm{Cu}_{6} \mathrm{Sn}_{5} / \mathrm{Sn}$ interface, hindered the flow of copper atoms to the solder thereby slowing down the IMC growth [36]. Thus, the segregation of $\mathrm{Al}$ atoms at the IMC/Sn interface may have similar effect on the growth of IMC, by hindering the flow of $\mathrm{Cu}$ or $\mathrm{Sn}$ atom. With minor $\mathrm{Al}$ addition, most of the $\mathrm{Al}$ reacts with $\mathrm{Cu}$ in the bulk solder to form $\mathrm{Cu}_{3} \mathrm{Al}_{2}$. Hence, $\mathrm{Al}$ does not form a layer of compound at the interface. Reduction of free $\mathrm{Cu}$ atom in the bulk solder could also be attributed to the retardation of $\mathrm{Cu}_{6} \mathrm{Sn}_{5}$ growth. When the amount of $\mathrm{Al}$ in the solder increased ( $\geqslant 0.5 \mathrm{wt} . \% \mathrm{Al}$ in $\mathrm{SA}, \geqslant 1 \mathrm{wt} . \% \mathrm{Al}$ in $\mathrm{SAC})$, it formed a layer of $\mathrm{Cu}-\mathrm{Al}$ compound at the solder/Cu interface $[15,16]$. By their presence at the interface, $\mathrm{Cu}_{3} \mathrm{Al}_{2} \mathrm{IMC}$ hinders the flow of $\mathrm{Cu}$ or $\mathrm{Sn}$ atom to the solder thereby retarding IMC growth during reflow.

During isothermal aging, the $\mathrm{Cu}_{6} \mathrm{Sn}_{5}$ IMC layer grows by interdiffusion of $\mathrm{Cu}$ and $\mathrm{Sn}$ and reaction with each other, while the $\mathrm{Cu}_{3} \mathrm{Sn}$ IMC forms and grows by reactions between the $\mathrm{Cu}$ substrate and $\mathrm{Cu}_{6} \mathrm{Sn}_{5} \mathrm{IMC}$ layer, as given in the equation below [11]:

$$
\mathrm{Cu}_{6} \mathrm{Sn}_{5}+9 \mathrm{Cu} \rightarrow 5 \mathrm{Cu}_{3} \mathrm{Sn}
$$

The presence of $\mathrm{Cu}_{3} \mathrm{Al}_{2} \mathrm{IMC}$ at the $\mathrm{Cu}_{6} \mathrm{Sn}_{5} / \mathrm{Sn}$ interface hinders the flow of $\mathrm{Cu}$ or $\mathrm{Sn}$ atom to the solder, however it does not affect the reaction in Equation (1). $\mathrm{Cu}_{3} \mathrm{Sn}$ grows by consuming $\mathrm{Cu}_{6} \mathrm{Sn}_{5}$ that is formed during reflow. Thus, the thickness of $\mathrm{Cu}_{3} \mathrm{Sn}$ was not significantly affected by the addition of $\mathrm{Al}$ in solder. On the other hand, with slower interdiffusion of $\mathrm{Cu}$ and $\mathrm{Sn}$ at the interface (due to presence of $\mathrm{Cu}_{3} \mathrm{Al}_{2}$ ) and $\mathrm{Cu}_{3} \mathrm{Sn}$ formation by consumption of $\mathrm{Cu}_{6} \mathrm{Sn}_{5}$, the thickness of $\mathrm{Cu}_{6} \mathrm{Sn}_{5}$ was reduced in $\mathrm{SAC} 105+\mathrm{Al}$ solder.

The addition of $\mathrm{Al}$ has increased the hardness of bulk solder. This could be due to the grain refinement of Sn, which can be seen in Figure 3. Kim et al. has also reported that addition of $\mathrm{Al}$ as low as $0.01 \mathrm{wt} . \%$ could refine the $\mathrm{Sn}$ grain of $\mathrm{Sn}-\mathrm{Cu}$ solder [8]. From nanoindentation, $\mathrm{Cu}_{3} \mathrm{Al}_{2}$ that are found in all SAC + Al solder exhibits higher hardness than other elements in SAC105 + Al. This seems promising in strengthening the solder joints. However, its high elastic modulus should be considered as well, as high elastic modulus could be detrimental for impact testing. Thus, further testing need to be done to further verify the effects of strengthening effects of $\mathrm{Cu}_{3} \mathrm{Al}_{2}$. 
In spite of the incorporation by only a small fraction, $\mathrm{Al}$ is clearly seen to have influenced decisively on the hardness, undercooling of solder and the interfacial characteristics during reflow. However, the amount of $\mathrm{Al}$ must be kept below $0.3 \mathrm{wt}$ \% in order to avoid large $\mathrm{Cu}_{3} \mathrm{Al}_{2}$ agglomeration, which could affect the performance of solder.

\section{Materials and Methods}

SAC105-xAl (where $x=0,0.1,0.3,0.5$ wt.\%) were fabricated by Beijing Compo Advanced Technology Co. Ltd. (Beijing, China). All the solder alloys were prepared in rod shape $(0.7 \mathrm{~cm}$ diameter, $15 \mathrm{~cm}$ length). The solder alloy was then cut into thin disks with $1 \mathrm{~mm}$ thickness by using electric discharge machining (EDM, A500W, Sodick, Schaumburg, IL, USA).

As-received solder was prepared for micro-examination by standard metallographic technique which included, cutting, mounting, grinding (up to 3000 grit paper) and polishing (diamond paste with size $9 \mu \mathrm{m}, 6 \mu \mathrm{m}, 3 \mu \mathrm{m}, 1 \mu \mathrm{m}$ and colloidal silica with size $0.2 \mu \mathrm{m}$ ). The microstructure of the as-received SAC105-Al solders was characterized by Field emission scanning electron microscope (FESEM, FEI-FEG450, FEI, Houston, TX, USA) and intermetallic compound (IMC) composition was investigated by energy dispersive X-ray spectroscope (EDS, EDAX-Genesis Utilities, EDAX, Mahwah, NJ, USA). Differential scanning calorimeter, DSC (DSC Q20, TA Instruments, New Castle, DE, USA) was used to evaluate the effect of the addition of $\mathrm{Al}$ on the onset melting and onset solidification temperature of the SAC105 solder. Each of the samples was weighed to approximately $10 \mathrm{mg}$ and placed on an aluminum pan and covered with a lid. It was then heated from $25^{\circ} \mathrm{C}$ to $300{ }^{\circ} \mathrm{C}$ and then cooled down to room temperature at a rate of $10^{\circ} \mathrm{C} / \mathrm{min}$. For each composition, DSC test was repeated 3 times to ensure the reproducibility of the DSC results.

For reflow, commercial grade polycrystalline copper $(\mathrm{Cu})$ sheets $(30 \mathrm{~mm} \times 30 \mathrm{~mm} \times 0.3 \mathrm{~mm})$ were used as substrates. Before soldering, $\mathrm{Cu}$ sheets were polished with 2000 Grit silica carbide paper, washed with detergent and soaked in 10 vol. $\% \mathrm{H}_{2} \mathrm{SO}_{4}$ solution for 15-30 min to remove any oxide film present. These were then rinsed with distilled water followed by drying with acetone. Sparkle Flux WF-6317 (Senju Metal Industry, Tokyo, Japan) was then evenly placed on the Cu substrate. SAC-xAl thin disc (diameter $=6.5 \mathrm{~mm}$, thickness $=1.24 \mathrm{~mm}$ ) were placed in the middle of copper substrates which had been covered with Flux WF-6317. Reflow was carried out in an oven at $250{ }^{\circ} \mathrm{C}$ for $60 \mathrm{~s}$. After the reflow process, the residual flux was cleaned and removed by rinsing the sample under running distilled water. After that, the reflowed samples were prepared by standard metallographic specimen preparation for microstructural investigation. The microstructure of the bulk solder and the morphology of the IMCs formed at the solder/substrate interface were investigated by FESEM and the composition of the IMCs was investigated by EDS. IMC thickness was calculated by dividing the IMC area by the length of the IMC using a built-in image analyzer software in an Olympus SZX10 (Olympus, Tokyo, Japan) stereoscope. For each experimental condition, thickness values were measured on 5 micrographs and the average IMC thickness is reported. For the top view observation of the interfacial IMCs, the solders were etched in a mixture of $93 \% \mathrm{CH}_{3} \mathrm{OH}, 5 \% \mathrm{HNO}_{3}$, and $2 \% \mathrm{HCl}$ to remove the solder matrix and expose the interfacial intermetallic compound.

Vickers hardness measurement was performed to investigate the relationship between microstructure and microhardness. The Vickers hardness values were obtained as [36]:

$$
\mathrm{HV}=2 \mathrm{P} \sin \varphi / 2 \mathrm{~d}
$$

where $\varphi$ is the indenter apex angle, $\mathrm{P}$ is the applied load and $\mathrm{d}$ is the average length of diagonals. The applied load and loading period are $1 \mathrm{kgf}$ and $5 \mathrm{~s}$, respectively. For each specimen, five points were tested and the mean values were obtained.

Nanoindentation testing was done using Hysitron Ubi-750 (Hysitron, Minneapolis, MI, USA). Two modes of indentation were conducted on the samples: Quasi-static and Continuous Dynamic Measurement. Quasi-static indentation was conducted with a maximum load of $500 \mu \mathrm{N}$, holding time of $2 \mathrm{~s}$, loading rate and unloading rate of $16.67 \mu \mathrm{N} / \mathrm{s}$ and continuous dynamic measurement test 
was conducted with a maximum of $1000 \mu \mathrm{N}$, holding time of $2 \mathrm{~s}$ and a loading rate and unloading rate of $16.67 \mu \mathrm{N} / \mathrm{s}$. For each element, 5 points were tested and the mean values were obtained. The load-displacement data obtained were analyzed using the method proposed by Oliver and Pharr [37] to determine the hardness and elastic modulus as functions of the displacement of the indenter. For quasi static nanoindentation testing, hardness $(\mathrm{H})$ and reduced modulus $(\mathrm{E})$ can be obtained. The elastic modulus $\mathrm{E}$ of the material being indented is related to the reduced modulus using the following equation [38]:

$$
E=\frac{1-v^{2}}{\frac{1}{E_{\mathrm{r}}}-\frac{1-v_{i}^{2}}{E_{i}}}
$$

where $v$ is the Poisson's ratio of the indented material (usually assumed to be 0.3 if unknown), and $v_{i}$ and $E_{i}$ are the Poisson's ratio and elastic modulus of the indenter tip material, respectively. The elastic modulus $\mathrm{E}_{\mathrm{i}}$ and Poisson's ratio $\mathrm{v}_{\mathrm{i}}$ of the Berkovich indenter used in this study are $1141 \mathrm{GPa}$ and 0.07 respectively. For continuous dynamic measurement, results for the hardness and complex modulus as a function of indentation depth can be obtained.

Complex modulus, which is also known as dynamic modulus, is a ratio of stress strain under vibratory conditions. It could be defined by the equation below [39]:

$$
\mathrm{E}^{*}=\mathrm{E}^{\prime}+\mathrm{i} \mathrm{E}^{\prime \prime}
$$

where $\mathrm{E}^{*}$ is the reduced complex modulus, $\mathrm{E}^{\prime}$ is the reduced storage modulus (or elastic modulus), $\mathrm{E}^{\prime \prime}$ is the loss modulus and $i$ is the imaginary unit.

\section{Conclusions}

The following conclusions can be drawn from this study:

- $\quad$ Minor addition of Al has reduced the undercooling of SAC105 solder significantly.

- With addition of 0.1-0.5 wt.\% $\mathrm{Al}$ to SAC105, $\mathrm{Cu}_{3} \mathrm{Al}_{2} \mathrm{IMC}$ was found.

- $\mathrm{Cu}_{3} \mathrm{Al}_{2} \mathrm{IMC}$ segregated near the edge of solder upon reflow as $\mathrm{Al}$ was added up to 0.3 wt.\%.

- Minor alloying $\mathrm{Al}$ has reduced the thickness of interfacial $\mathrm{Cu}_{6} \mathrm{Sn}_{5} \mathrm{IMC}$ significantly but do not alter the morphology of $\mathrm{Cu}_{6} \mathrm{Sn}_{5} \mathrm{IMC}$.

- Minor alloying $\mathrm{Al}$ has reduced the thickness of interfacial $\mathrm{Cu}_{6} \mathrm{Sn}_{5} \mathrm{IMC}$ but has no significant effect on the thickness of $\mathrm{Cu}_{3} \mathrm{Sn}$ during isothermal aging.

- It is suggested that the influence of $\mathrm{Al}$ exert its influence on the interfacial reaction by hindering the flow of reacting species at the interface during reflow.

- $\mathrm{Cu}_{3} \mathrm{Al}_{2}$ IMC has higher hardness and elastic modulus than other microstructure in SAC105 + Al microstructures.

Acknowledgments: The authors would like to acknowledge the financial support from High Impact Research (HIR) Grant, University of Malaya (Project No. UM.C/625/1/HIR/MOHE/ENG/26).

Author Contributions: Y.M.L. and A.S.M.A.H. conceived and designed the experiments; Y.M.L. performed the experiments; Y.M.L. and A.S.M.A.H. analyzed the data; A.S.M.A.H. contributed reagents $/$ materials/analysis tools; and Y.M.L. and A.S.M.A.H. wrote the paper.

Conflicts of Interest: The authors declare no conflict of interest.

\section{References}

1. Kang, S.K.; Shih, D.-Y.; Leonard, D.; Donald, N.Y.; Henderson, D.W.; Gosselin, T.; Sarkhel, A.; Goldsmith, N.Y.C. $\mathrm{Ag}_{3} \mathrm{Sn}$ plate formation in the solidification of near-ternary eutectic Sn-Ag-Cu. JOM 2004, 56, 34-38. [CrossRef]

2. Shnawah, D.A.A.; Sabri, M.F.M.; Badruddin, L.A.; Said, S.B.M.; Che, F.X. The bulk alloy microstructure and mechanical properties of Sn-1Ag-0.5Cu-xAl solders ( $\mathrm{x}=0,0.1$ and $0.2 \mathrm{wt} \%)$. J. Mater. Sci. Mater. Electron. 2012, 23, 1988-1997. [CrossRef] 
3. Burke, C.; Punch, J.A. Comparison of the Creep Behavior of Joint-Scale SAC105 and SAC305 Solder Alloys. In Proceedings of the IEEE Transactions on Components, Packaging and Manufacturing Technology, Kyoto, Japan, 12 February 2014; pp. 516-527.

4. Cheng, F.; Gao, F.; Zhang, J.; Jin, W.; Xiao, X. Tensile properties and wettability of SAC0307 and SAC105 low Ag lead-free solder alloys. J. Mater. Sci. 2011, 46, 3424-3429. [CrossRef]

5. Liu, W.; Lee, N.C. The effects of additives to $\mathrm{SnAgCu}$ alloys on microstructure and drop impact reliability of solder joints. JOM 2007, 56, 26-31. [CrossRef]

6. Lee, T.; Bieler, T.R.; Kim, C.; Ma, H. Fundamentals of Lead-Free Solder Interconnect Technology; Springer: New York, NY, USA, 2015.

7. Ahmad, A.E. Evolution of microstructure, thermal and creep properties of Ni-doped Sn-0.5Ag-0.7Cu low-Ag solder alloys for electronic applications. Mater. Des. 2013, 52, 663-670.

8. Kim, K.S.; Huh, S.H.; Suganuma, K. Effects of fourth alloying additive on microstructures and tensile properties of Sn-Ag-Cu alloy and joints with Cu. Microelectron. Reliab. 2003, 43, 259-267. [CrossRef]

9. Anderson, I.E.; Walleser, J.W.; Harringa, J.L.; Laabs, F.; Kracher, A. Nucleation control and thermal aging resistance of near-eutectic Sn-Ag-Cu-X solder joints by alloy design. J. Electron. Mater. 2009, 38, 2770-2779. [CrossRef]

10. Shi, Y.W.; Tian, J.; Hao, H.; Xia, Z.; Lei, Y.; Guo, F. Effects of small amount addition of rare earth Er on microstructure and property of SnAgCu solder. J. Alloys Compd. 2008, 453, 180-184. [CrossRef]

11. Laurila, T.; Vuorinen, V.; Paulasto-Kröckel, M. Impurity and alloying effects on interfacial reaction layers in Pb-free soldering. Mat. Sci. Eng. R 2010, 68, 1-38. [CrossRef]

12. Amagai, M.A. study of nanoparticles in Sn-Ag based lead free solders. Microelectron. Reliab. 2008, 48, 1-16. [CrossRef]

13. Gain, A.K.; Chan, Y.C. The influence of a small amount of $\mathrm{Al}$ and Ni nano-particles on the microstructure, kinetics and hardness of Sn-Ag-Cu solder on OSP-Cu pads. Intermetallics 2012, 29, 48-55. [CrossRef]

14. Boesenberg, A.J.; Anderson, I.E.; Harringa, J.L. Development of Sn-Ag-Cu-X Solders for Electronic Assembly by Micro-Alloying with Al. J. Electron. Mater. 2012, 41, 1868-1881. [CrossRef]

15. Xia, Y.H.; Jee, J.K.; Yu, J.; Lee, T.Y. Effect of aluminum concentration on the interfacial reactions of Sn-3.0Ag-xAl solders with copper and ENIG metallizations. J. Electron. Mater. 2008, 37, 1858-1862. [CrossRef]

16. Li, J.F.; Agyakwa, P.A.; Johnson, C.M. Effect of trace Al on growth rates of intermetallic compound layers between Sn-based solders and Cu substrate. J. Alloys Compd. 2012, 545, 70-79. [CrossRef]

17. Kantarcioğlu, A.; Kalay, Y.E. Effects of Al and Fe additions on microstructure and mechanical properties of SnAgCu eutectic lead-free solders. Mat. Sci. Eng. A 2014, 593, 79-84. [CrossRef]

18. Kotadia, H.R.; Panneerselvam, A.; Mokhtari, O.; Green, M.A.; Mannan, S.H. Massive spalling of Cu-Zn and $\mathrm{Cu}-\mathrm{Al}$ intermetallic compounds at the interface between solders and $\mathrm{Cu}$ substrate during liquid state reaction. J. Appl. Phys. 2012, 111, 074902-074906. [CrossRef]

19. Mohd, F.M.S.; Dhafer, A.S.; Irfan, A.B.; Suhana, B.M.S. Effects of aging on Sn-1Ag-0.5Cu solder alloys containing $0.1 \mathrm{wt} \%$ and $0.5 \mathrm{wt} \%$ Al. J. Alloys Compd. 2014, 582, 437-446.

20. Dhafer, A.S.; Mohd, F.M.S.; Suhana, B.M.S.; Iswadi, J.; Mohammad, H.M.; Mohamed, B.A.B.; Mohamed, H.E. Interfacial reactions between $\mathrm{Cu}$ substrate and $\mathrm{Sn}-1 \mathrm{Ag}-0.5 \mathrm{Cu}$ solder containing $0.1 \mathrm{wt} . \% \mathrm{Al}$ by dipping method. J. Mater. Sci. Mater. Electron. 2015, 26, 8229-8239.

21. Whitehead, A.J.; Page, T.F. Nanoindentation studies of thin film coated systems. Thin Solid Films 1992, 220, 277-283. [CrossRef]

22. Song, J.-M.; Huang, B.-R.; Liu, C.-Y.; Lai, Y.-S.; Chiu, Y.-T.; Huang, T.-W. Nanomechanical responses of intermetallic phase at the solder joint interface-Crystal orientation and metallurgical effects. Mater. Sci. Eng. A 2012, 534, 53-59. [CrossRef]

23. Saunders, N.; Miodownik, A.P. The Cu-Sn (Copper-Tin) system. Alloy Phase Diagram Evaluations. Bull. Alloy Phase Diagr. 1990, 11, 278-287. [CrossRef]

24. Funamizu, Y.; Watanabe, K. Interdiffusion in the Al-Cu system. Trans. Jpn. Inst. Met. 1971, 12, 147. [CrossRef]

25. Molnár, A.; Kardos, I.; Molnár, I.; Gácsi, Z. Effect of silver content on the properties of lead-free solders. Mater. Sci. Eng. 2014, 39, 51-58.

26. Chen, H.-T.; Ya, B.-B.; Yang, M.; Ma, X.; Mingyu, L. Effect of grain orientation on mechanical properties and thermomechanical response of Sn-based solder interconnects. Mater. Charact. 2013, 85, 64-72. [CrossRef] 
27. Maleki, M.; Cugnoni, J.; Botsis, J. Microstructure-based modeling of the ageing effect on the deformation behavior of the eutectic micro-constituent in SnAgCu lead-free solder. Acta Mater. 2013, 61, 103-114. [CrossRef]

28. Marquesa, V.M.F.; Wunderleb, B.; Johnstona, C.; Granta, P.S. Nanomechanical characterization of $\mathrm{Sn}-\mathrm{Ag}-\mathrm{Cu} / \mathrm{Cu}$ joints-Part 2: Nanoindentation creep and its relationship with uniaxial creep as a function of temperature. Acta Mater. 2013, 61, 2460-2470. [CrossRef]

29. Lotfian, S.; Molina-Aldareguia, J.M.; Yazzie, K.E.; Llorca, J.; Chawla, N. Mechanical characterization of lead-free Sn-Ag-Cu solder joints by high-temperature nanoindentation. J. Electron. Mater. 2013, 42, 1085-1091. [CrossRef]

30. Karakaya, I.; Thompson, W.T. The Ag-Sn (Silver-Tin) system. Bull. Alloy Phase. Diagr. 1987, 8, $340-347$. [CrossRef]

31. Katoh, R.; Munekata, O.; Toyoda, Y. Tombstoning Prevented by the Use of a Twin-Peak Solder Alloy. U.S. Patent 6554180 B1, 29 April 2003.

32. Kubaschewski, O.; Hari Kumar, K.C. Materials Science International Team MSIT ${ }^{\circledR}$, Ag-Cu-Sn (Silver-Copper-Tin). In Non-Ferrous Met. Ternary Systems; Springer: Berlin, Germany, 2007; pp. 47-62.

33. Massalski, T.B. The Al-Cu (Aluminum-Copper) system. Bull. Alloy Phase Diagr. 1980, 1, 27-33. [CrossRef]

34. Kotadia, H.R.; Mokhtari, O.; Bottrill, O.M.; Clode, M.P.; Green, M.A.; Mannan, S.H. Reactions of Sn-3.5Ag-Based Solders Containing Zn and Al Additions on $\mathrm{Cu}$ and $\mathrm{Ni}(\mathrm{P})$ Substrates. J. Electron. Mater. 2010, 39, 2720-2731. [CrossRef]

35. Chauhan, P.S.; Choubey, A.; Zhong, Z.W.; Pecht, M.G. Copper Wire Bonding; Springer: New York, NY, USA, 2014.

36. Haseeb, A.S.M.A.; Leong, Y.M.; Arafat, M.M. In-Situ Alloying of Sn-3.5Ag Solder during Reflow through Zn Nanoparticle Addition and Its Effects on Interfacial Intermetallic Layers. Intermetallics 2014, 54, 86-94. [CrossRef]

37. Oliver, W.C.; Pharr, G.M. Measurement of hardness and elastic modulus by instrumented indentation: Advances in understanding and refinements to methodology. J. Mater. Res. 2004, 19, 3-20. [CrossRef]

38. Fischer-Cripps, A.C. Nanoindentation, 3rd ed.; Springer: New York, NY, USA, 2011; pp. $2-126$.

39. Meyers, M.A.; Chawla, K. Mechanical Behavior of Materials, 2nd ed.; Cambridge University Press: Cambridge, UK, 2008. 